\title{
ANALISIS PENERIMAAN PENGGUNA SISTEM INFORMASI PERPUSTAKAAN DAN ARSIP DAERAH KABUPATEN BULELENG MENGGUNAKAN MODEL UNIFIED THEORY OF ACCEPTANCE AND USE OF TECHNOLOGY (UTAUT)
}

\author{
Ni Ketut Nita Rianadewi ${ }^{1}$, Dewa Gede Hendra Divayana ${ }^{2}$, IMade Ardwi Pradnyana ${ }^{3}$ \\ Program Studi Pendidikan Teknik Informatika \\ Jurusan Teknik Informatika \\ Fakultas Teknik dan Kejuruan \\ Universitas Pendidikan Ganesha \\ Email :nitadewi98@gmail.com¹,hendra.divayana@undiksha.ac.id ${ }^{2}$,ardwi.pradnyana@undiksha.ac.id ${ }^{3}$
}

\begin{abstract}
Abstrak- Sistem Informasi Perpustakaan dan Arsip (SIPA) adalah sebuah website yang dikembangkan oleh perpustakaan daerah di kabupaten Buleleng sebagai alternative dalam mendukung pengelolaan dan mempermudah pengguna. Penelitian ini bertujuan untuk menganalisis pemanfaatan Sistem Informasi Perpustakaan dan Arsip (SIPA) di Kabupaten Buleleng dengan berdasarkan menggunakan Model Unified Theory Of Acceptance and Use Of Technology (UTAUT) dengan menggunakan empat variabel bebas yakni performance expectancy, effort expectancy, social influence dan facilitating conditions sebagai variable bebas dengan behavioral intention dan use behavior sebagai variable terikat dan variable moderator Age, Gender dan experience.

Variabel Ekpektansi Kinerja dan variabel Ekspektasi usaha tidak berpengaruh positif terhadap minat penggunaan Sistem Informasi Perpustakaan. Pengaruh sosial berpengaruh positif terhadap minat penggunaan, Kondisi yang memfasilitasi berpengaruh positif terhadap perilaku penggunaan Sistem Informasi Perpustakaan, Variabel moderator jenis kelamin tidak memperkuat hubungan antara ekspektasi kinerja, ekspektansi usaha dan pengaruh sosial terhadap minat penggunaan Sistem Informasi Perpustakaan. Variabel moderator umur tidak memperkuat hubungan antara ekspektasi kinerja, ekspektansi usaha dan pengaruh sosial dengan minat penggunaan.Variabel moderator umur memperkuat hubungan antara kondisi yang memfasilitasi dengan perilaku pengguna, variable moderator pengalaman memperkuat hubungan antara pengaruh sosial terhadap minat penggunaan Sistem Informasi Perpustakaan, variable moderator pengalaman memperkuat hubungan antara kondisi yang memfasilitasi terhadap perilaku pengguna Sistem Informasi Perpustakaan.
\end{abstract}

Kata Kunci : Sistem Informasi Perpustakaan, EkspektansiKinerja, Ekspektansi Usaha, Pengaruh Sosial, Kondisi Pemfasilitasi, Minat Penggunaan, Perilaku pengguna, UTAUT

Abstract - Library and Archive Information System (SIPA) is a website developed by regional libraries in Buleleng Regency as an alternative in supporting management and facilitating users. This study aims to analyze the use of Library and Archive Information Systems (SIPA) in Buleleng Regency based on using the Unified Theory of Acceptance and Use of Technology (UTAUT) Model by using four independent variables namely performance expectancy, effort expectancy, social influence and facilitating conditions as independent variable with behavioral intention and use behavior as bound variables and moderator variables Age, Gender and experience

Performance Expectation Variables and effort Expectancy variables have no positive effect on interest in using the Library Information System. Social influence has a positive effect on interest in use, facilitating conditions have a positive effect on the behavior of the Library Information System, gender moderator variables do not strengthen the relationship between performance expectations, effort Expectancy and social influences on interest in using the Library Information System. Age moderator variables do not strengthen the relationship between performance expectations, effort Expectancy and social influences with interest in use. Age moderator variables reinforce the relationship between conditions that facilitate user behavior. Experience moderator variables strengthen the relationship between social influence on interest in using Library Information Systems, experience moderator variables. Strengthen the relationship between conditions that facilitate the behavior of Library Information Systems users.

Keywords : Performance Expectancy, effort Expectancy, Social Influence, Behavioral intention, User Behavioral, UTAUT.

\section{PENDAHULUAN}

Perkembangan teknologi informasi saat ini sangat pesat, hampir seluruh kegiatan atau aktfitas manusia sudah di bantu oleh komputer, peranan ilmu pengetahuan dan teknologi yang sangat berpengaruh terhadap kemajuan bisnis, baik secara individual, instansi pemerintah, ataupun swasta. Perkembangan informasi mempunyai peranan yang sangat penting di dalam suatu usaha menciptakan kemajuan di semua bidang yang diperuntukkan bagi kepentingan manusia pada umumnya.

Sistem informasi merupakan salah satu alat bantu setiap individu dalam melakukan kegiatan mencari dan menemukan informasi berbasis internet. Salah satu sistem informasi yang dapat digunakan adalah sistem informasi perpustakaan. Sistem informasi perpustakaan dapat membantu individu dalam memenuhi kebutuhan dalam mencari referensi dlam proses belajar mengajar serta kebutuhan dalam mengelola buku secara terstruktur dan sistematik. Selain itu sistem informasi perpustakaan menjadi 
nilai tambah bagi organisasi juga meningkatkan kinerja perpustakaan itu sendiri.

Pada Sistem Informasi Perpustakaan Dan Arsip Daerah Kabupaten Buleleng terdapat enam menu utama yaitu beranda depan, info perpustakaan, area anggota, pustakawan, bantuan pencarian dan masuk pustakawan. Sebelum digunakannya Sistem Informasi Perpusatakaan sebagian pustakawannya masih menggunakan cara konvensional, namun kini setelah digunakannya sistem tersebut pekerjaan pustakawan lebih efektif dan efisien.

Namun setelah peneliti melakukan observasi kepada pengguna yaitu anggota Perpustakaan daerah, ditemukan beberapa masalah yaitu kurangnya fasilitas untuk pencarian buku seperti komputer, kemudian pada proses pendaftaran anggota masih menggunakan cara manual, dan kurangnya sosialisasi atau pendekatan kepada pengguna mengenai SIPA yang berpengaruh terhadap minat pemanfaatan untuk mengakses sistem ini.

Berdasarkan hal tersebut agar mampu mengatasi permasalahan terkait dengan belum digunakannya secara optimal sistem informasi perpustakaan daerah kabupaten buleleng (SIPA) dan untuk mendapatkan manfaat yang sesuai dengan harapan, sistem informasi perpustakaan daerah kabupaten buleleng harus diterima dan digunakan dengan optimal oleh pengguna sehingga dapat memberikan kontribusi terhadap kemajuan sistem tersebut. untuk mengetahui tingkat penerimaan penggunaan terhadap pengguna sistem informasi perpustakaan daerah kabupaten buleleng dapat diukur menggunakan salah satu pendekatan teori penerimaan dan penggunaan terhadap suatu teknologi dengan menggunakan metode UTAUT.

Dalam penelitian ini menggunakan model UTAUT dengan empat variabel independen atau variabel bebas seperti (1) ekspektasi kinerja dimana pengguna merasa saat menggunakan SIPA dari segi waktu dalam pekerjaannya akan memungkinkan untuk menyelesaikan tugasnya lebih cepat, (2) ekspektasi usaha dimana pengguna akan merasa lebih mudah menggunakan SIPA untuk melakukan apa yang ingin dikerjakan, (3) pengaruh sosial dimana orang-orang disekitar yang mempengaruhi perilaku pengguna dalam berpikir bahwa pengguna harus menggunakan SIPA untuk mempermudah pekerjaannya dan (4) kondisi yang memfasilitasi dimana pengguna memiliki pengetahuan dan fasilitas yang mendukung untuk menggunakan SIPA.

Penelitian ini ingin mengetahui pengujian penerimaan terhadap system informasi perpustakaan daerah kabupaten Buleleng sehingga diketahui apakah variabel bebas seperti ekspektasi kinerja, ekspektasi usaha dan pengaruh sosial akan diuji apakah berpengaruh terhadap minat penggunaan, kemudian kondisi fasilitas dan minat pengguna akan diuji apakah berpengaruh terhadap perilaku pengguna dan variable moderator seperti jenis kelamin, usia dan pengalaman akan mempengaruhi penggunaaan SIPA. Berdasarkan pemaparan tersebut, maka peneliti akan melakukan penelitian yang berjudul Analisi Penerimaan pengguna Sistem Informasi Perpustakaan Dan Arsip Daerah Kabupaten Buleleng Menggunakan Model UTAUT”.

\section{KAJIAN PUSTAKA}

\section{A. Penelitian Terkait}

Dari hasil tersebut dapat disimpulkan bahwa metode UTAUT merupakan metode yang paling baik digunakan dalam studi kasus ini sebab metode UTAUT mampu mengukur sebanyak 70,7 \% dari aspek-aspek yang dapat digunakan untuk menilai kesuksesan penerapan sebuah sistem dan metode TAM hanya mampu mengukur sebanyak 62,1\%. [1], yaitu "Analisis Penerapan Model Utaut (Unified Theory Of Acceptance And Use Of Technology)Terhadap Perilaku Pengguna Sistem Informasi (Studi Kasus: Sistem Informasi Akademik Pada Sttnas Yogyakarta)" didapatkan hasil 1. Berdasarkan analisis, diketahui bahwa variabel Performance Expectancy (PE), Social Influence (SI) dan Facilitating Condition (FC) berpengaruh secara signifikan terhadap Behavioral Intention, sedangkan variabel Effort Expectancy (EE) memberikan hasil yang tidak signifikan. 2. Secara keseluruhan keempat prediktor tersebut hanya mampu menjelaskan pengaruh terhadap behavioral intention sebesar 37,6\%[1].[3], melakukan penelitian yang berjudul "Pengaruh Penerapan Remote ElectronicVoting System (REVS) Terhadap Tingkat Partisipasi Pemilih Menggunakan model UTAUT". Penelitian ini bertujuan untuk melihat pengaruh penerapan teknologi REVS terhadap tingkat partisipasi masyarakat berdasarkan prototipe e-voting yang sudah dibuat yaitu indo-vote.Beberapa variabel diuji dengan menggunakan teknik analisis Partial Least Square (PLS) atau biasa disebut variancebased SEM, tools yang digunakan untuk menganalisis hubungan antar variabel tersebut, menggunakan SmartPLS 2.0[3]. Berdasarkan hasil analisis dan pembahasan pada bagian sebelumnya, maka dapat disimpulkan bahwa penggunaan model UTAUT yang terdiri dari faktor performance expectancy, mobility dan security \& privacy telah terbukti dapat mempengaruhi diterimanya sistem REVS oleh pemilih. Namun variabel effort expectancy, facilitating condition dan experience tidak mempengaruhi penerimaan sistem REVS.

\section{B. Sistem Informasi}

Sistem informasi merupakan suatu sinergi antara data, mesin pengolah data (yang biasanya meliputi computer, program aplikasi dan jaringan)dan manusia untuk menghasilkan informasi. Sistem informasi ada pada hampir 
setiap perusahaan atau organisasi untuk mendukung kegiatan bisnis sehari-hari [2].

Berdasarkan beberapa pendapat yang dikemukakan diatas dapat ditarik kesimpulan bahwa sistem informasi adalah sebuah sistem yang terdiri dari pengumpulan, pemasukan, pemrosesan data, penyimpanan, pengolahan, pengendalian, dan pelaporan sehingga tercapai sebuah informasi yang mendukung pengambilan keputusan didalam suatu organisasi untuk dapat mencapai sasaran dan tujuannya.serta sistem tersebut mampu menyediakan informasi yang bermanfaat bagi penggunanya.

\section{Sistem Informasi Perpustakaan}

Sistem Informasi Perpustakaan merupakan sekumpulan subsistem di suatu perpustakaan yang saling berinteraksi satu sama lain untuk mencapai tujuan bersama berupa pengelolaan dan penyediaaan informasi perpustakaan sehingga apabila informasi diperlukan dapat disediakan dengan cepat, mudah dan lengkap [2].

\section{Unified Theory of Acceptance And Use Of} Technology (UTAUT)

UTAUT merupakan salah satu model penerimaan teknologi terkini yang dikembangkan oleh Venkatesh dkk [4]. UTAUT menggabungkan fitur-fitur yang berhasil dari delapan teori penerimaan teknologi terkemuka menjadi satu teori. Kedelapan teori terkemuka yang disatukan di dalam UTAUT adalah theory of reasoned action(TRA), technology acceptance model(TAM), motivational model(MM), theory of planned behavior(TPB), combined TAM and TPB, model of PC utilization(MPTU), innovation diffusion theory(IDT), dan social cognitive theory(SCT) [4].

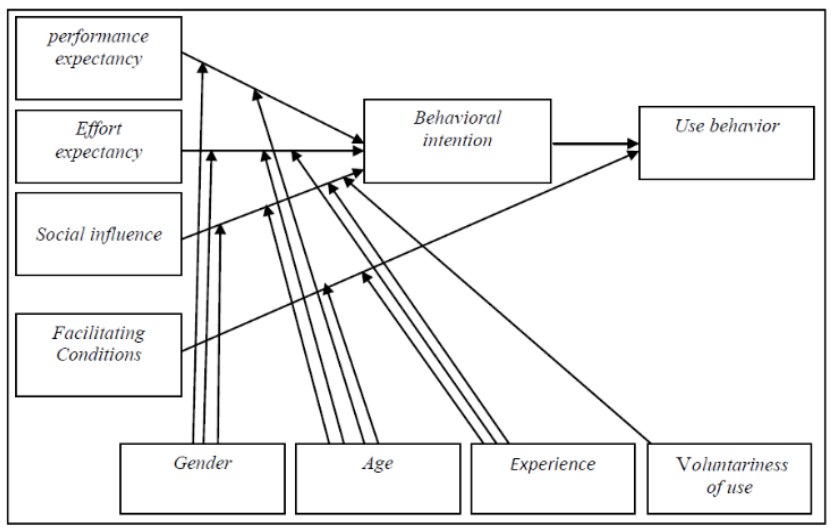

Gambar 1. Model UTAUT

\section{E. Partial Least Squares (PLS)}

PLS merupakan metode analisis yang powerful karena dapat diterapkan pada semua skala data, tidak membutuhkan banyak asumsi dan ukuran sampel tidak harus besar. PLS selain dapat digunakan sebagai konfirmasi teori juga dapat digunakan untuk membangun hubungan yang belum ada landasan terorinya atau untuk pengujian proposisi. PLS juga dapat digunakan untuk pemodelan structural dengan indiaktor bersifat reflektif ataupun formatif [5].

\section{F. Populasi dan Sampel Penelitian}

Jumlah anggota sampel sering dinyatakan dengan ukuran sampel. Jumlah sampel yang diharapkan 100\% mewakili populasi adalah sama dengan jumlah anggota populasi itu sendiri. Jadi bila jumlah populasi 1000 dan hasil penelitian itu akan diberlakukan untuk 1000 orang tersebut tanpa ada kesalahan, maka jumlah sampel yang diambil sama dengan jumlah populasi tersebut yaitu 1000 orang. Makin besar jumlah sampel mendekati populasi, maka peluang kesalahan generalisasi semakin kecil dan sebaliknya makin kecil jumlah sampel menjauhi populasi, maka makin besar kesalahan generalisasi [6]. Menurut [7] sampel adalah wakil semua unit strata dan sebagainya yang ada di dalam populasi.

\section{G. Skala Pengukuran dan Instrumen Penelitian}

Skala pengukuran merupakan kesepakatan yang digunakan sebagai acuan untuk menentukan panjang pendeknya interval yang ada dalam alat ukur, sehingga alat ukur tersebut bila digunakan dalam pengukuran akan menghasilkan data kuantitatif [6]. Salah satu skala pengukuran yaitu skala likert. Dengan skala likert, maka variabel yang akan diukur dijabarkan menjadi indicator variabel.

\section{H. Instrumen Penelitian}

Instrumen adalah pengukuran terhadap fenomena social maupun alam. Jumlah instrument penelitian tergantung pada jumlah variable penelitian yang telah ditetapkan untuk diteliti [6].

\section{Uji Coba Instrumen}

Dengan menggunakan instrumen yang valid dan reliabel dalam pengumpulan data, maka diharapkan hasil penelitian akan menjadi valid dan reliabel. Jadi instrumen yang valid dan reliabel merupakan syarat mutlak untuk mendapatkan hasil penelitian y ang valid dan reliable [6]. Dalam penelitian ini dilakukan uji validitas untuk menunjukkan tingkat kevalidan atau kesahihan sesuatu instrument. Suatu instrument yang valid atau sahih mempunyai validitas yang tinggi. Sebaliknya, instrumen yang kurang valid berarti memiliki validitas rendah [8].

\section{III.METODOLOGI PENELITIAN}

Teknik analisis data yang digunakan dalam penelitian ini adalah Structural Equation Modelling (SEM) dengan teknik Partial Least Square (PLS). Termologi yang digunakan pada 
PLS adalah bahwa tahap pertama disebut dengan pengujian model pengukuran (measurement model) atau model luar (outer model) dan tahap kedua disebut dengan pengujian model structural (structural model) atau model dalam (inner model) [9].

\section{A. Evaluasi Model Pengukuran (Outer Model)}

Teknik analisis data yang digunakan dalam penelitian ini adalah Structural Equation Modelling (SEM) dengan teknik Partial Least Square (PLS). Termologi yang digunakan pada PLS adalah bahwa tahap pertama disebut dengan pengujian model pengukuran (measurement model) atau model luar (outer model) dan tahap kedua disebut dengan pengujian model structural (structural model) atau model dalam (inner model) [9].

\section{B. Model Struktural (Inner Model)}

Evaluasi model struktural (inner model) adalah dengan mengevaluasi melihat nilai dari signifikansi hubungan antara variable.

\section{HASIL \&PEMBAHASAN}

\section{A. Hasil Uji Gregory}

Agar validitas isi instrument terpenuhi, peneliti menggunakan dua pakar yang dianggap menguasai variable yang sedang diteliti untuk menilai instrument yang sudah dikembangkan [10].

\section{B. Uji Validitas}

Uji validitas dilakukan dengan menggunakan SPSS. Kuisioner peneliti uji cobakan ke 30 responden diluar sampel peneliti. Butir dinyatakan valid apabila $r_{\text {hitung }}<r_{\text {Tabel }}$. Jumlah responden ujicoba $\mathrm{n}=30$; maka rtabel $=0,361$.

Hasil pengujian validitas kuisioner menunjukan ada 18 item pernytaan kuisioner yang nilai nya rhitung < rtabel yaitu pada pernyataan nomor $4,5,9,12,17,18$ pada variable ekspektansi kinerja, nomor 21, 26, 28, 32 pada variabel ekspektansi usaha, nomor $35,37,40,42,43$ pada variable faktor sosial dan nomor 49, 52, 56 pada variable kondisi memfasilitasi. Kemudian 18 item pernyataan tersebut dihapus dan tidak diikutsertakan saat penyebaran kuisioner dilapangan.

Item untuk variabel Minat Penggunaan dan Perilaku Pengguna diturunkan berdasarkan item kuisioner dalam penelitian yang disesuaikan dengan Sistem Informasi Perpustakaan

\section{Uji Reliabilitas}

Uji reliabilitas dilakukan dengan menggunakan SPSS yang menunjukkan nilai cronbach alpha. Nilai cronbach alpha pada pengujian reliabilitas ini adalah 0,914 dari 56 butir pernyataan yang diujicobakan kepada 30responden pengguna yaitu masyarakat pengguna Sistem Informasi Perpustakaan.

\section{Karakteristik Reponden}

Deskripsi karakteristik responden dari penelitian ini meliputi jenis kelamin, umur dan pengalaman. Sampel yang digunakan dalam penelitian ini sebanyak 60 responden yang sudah pernah menggunakan Sistem Informasi Perpustakaan. Berikut merupakan gambar data responden penelitian:

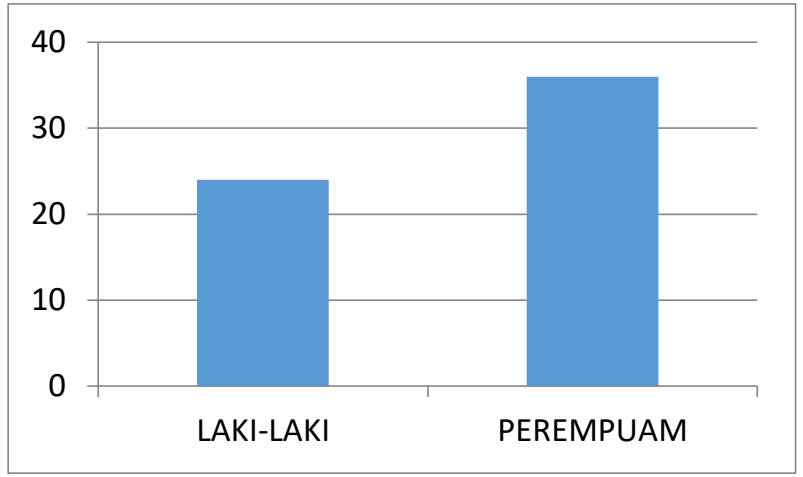

Gambar 2.Data responden penelitian

Jenis Kelamin responden menunjukan bahwa ada sebanyak 24 responden berjenis kelamin laki - laki serta yang berjenis kelamin perempuan berjumlah 36 responden.

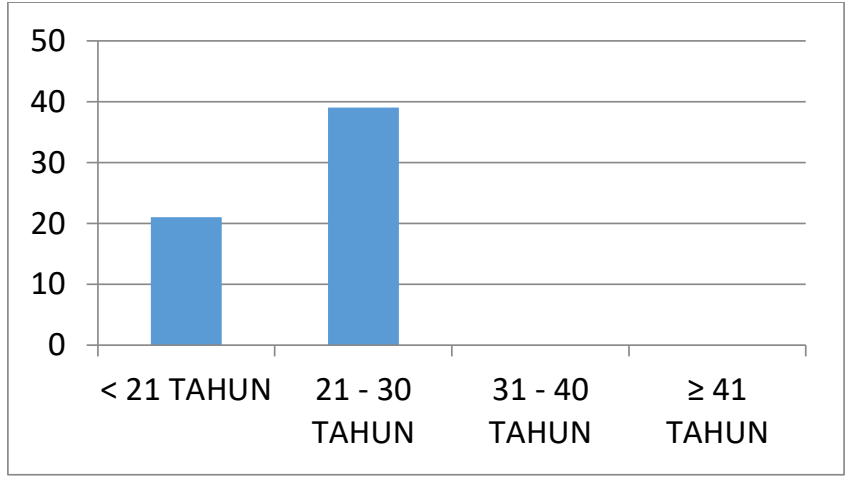

Gambar 3. Data umur

Umur responden menunjukkan bahwa responden yang berumur <21 berjumlah 21 orang, untuk responden berumur 21 sampai 30 tahun berjumlah 39 orang, responden yang berumur 31 sampai 40 tahun dan responden yang berumur $\geq$ 
ISSN 2252 - 9063

Kumpulan Artikel Mahasiswa Pendidikan Teknik Informatika

(KARMAPATI)

41 tidak ada dalam pengambilan sampel yang peniliti lakukan

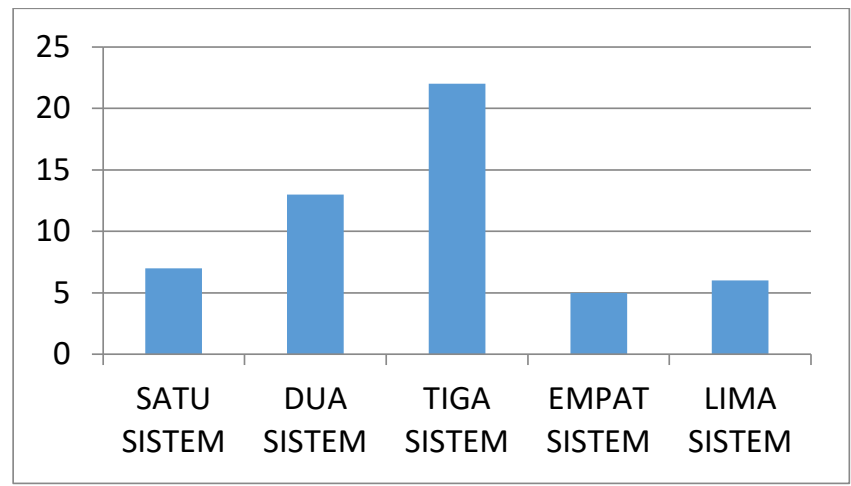

Gambar 4. Pengalaman responden menggunakan sistem informasi

Pengalaman responden yang pernah menggunakan sistem lain dalam kehidupan sehari - hari yaitu sebanyak 7 orang responden pernah menggunakan satu sistem informasi, 13 orang responden pernah menggunakan dua sistem informasi, 22 orang responden pernah menggunakan tiga sistem informasi, 5 orang responden pernah menggunakan empat sistem informasi dan sebanyak 6 orang responden menggunakan lima sistem lain dalam hal ini system yang tercantum dalam kuisioner yaitu Sistwm Informasi Perpustakaan, E-commerce, E-government, Email, Media Sosial.

\section{E. Analisis Model Pengukuran (Outer Model)}

\section{Uji Individual Item Reliability}

Nilai yang ideal untuk menyatakan suatu indikator itu valid adalah diatas 0,7. Jika hal ini tidak dipenuhi, indikator yang nilai loadingnya kurang dari 0,7 harus dihapus dari diagram jalur yang diusulkan karena indikator tersebut nilai reliabilitas dan validitasnya jelek [9].

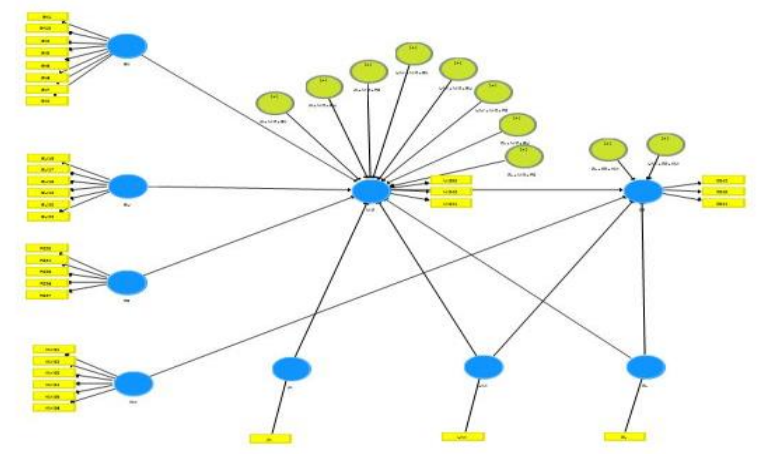

Gambar 5. Model Diagram Jalur menggunakan SmartPLS

\section{Uji Internal Consitency Reliability}

Uji Internal Consitency Reliability merupakan gabungan reabilitas indicator ke variable melihat nilai cronbach's alpha dan composite reliability yang minimal nilainya 0,7 (Santoso, 2018).

\section{Uji Average Variance Extracted (AVE)}

Pengujian Average Variance Extracted termasuk dalam pengujian Convergent Validity yang digunakan untuk menunjuukan ukuran sejauh mana sebuah indicator berkolerasi politik terhadap indicator lain terhadap indicator konstruk yang sama. Nilai AVE minimal 0,5 menunjukkan ukuran yang baik [9].

\section{Uji Disccriminant Validity}

Discriminant Validity diuji pada level indicator dan variable. Pada level indicator tidak ada indicator yang yang memberikan loading ke variable yang lebih tinggi dibandingkan variable yang seharusnya[9].

Berdasarkan hasil dari langkah - langkah setiap pengujian yang ada pada model pengukuran, menunjukan bahwa yang diajukan peneliti mempunyai nilai statistic yang baik. Maka dari itu, dapat diartikan bahwa model tersebut memenuhi syarat untuk dilanjutkan kedalam pengujian struktur model (inner model).

\section{F. Analisis Model Struktural (Inner Model)}

\section{Asesmen Kolinearitas}

Kolinearitas pada tingkat konstruk diukur dengan menggunakan kriteria yang sama dengan pengujian kolinearitas pada tingkat indicator, yakni dengan menggunakan toleransi VIF. Jika nilai VIF $>=0,5$ menunjukkan bahwa dua konstruk tersebut mempunyai persoalan kolinearitas [9].Hasil nilai kolinieritas yang dilihat dari VIF tidak ada nilai yang lebih dari 5 sehingga indikator tersebut tidak mempunyai persoalan kolinearitas.

\subsection{Koefesien Jalur}

Koefesien jalur mempunyai nilai terstandarisasi antara nilai -1 dan +1 . Nilai koefesien jalur yang mendekati +1 menunjukkan adanya relasi positif yang sangat kuat dari variable yang direlasikan. Nilai yang mendekati -1 menunjukkan adanya relasi negative yang sangat kuat. Jika koefesien jalur mempunyai nilai yang menjauhi nol biasanya signifikan secara statis [9]

\subsection{Koefesien Determinasi}

Koefesien determinasi menunjukkan kombinasipengaruh pengaruh variable bebas ke variable terikat. Nilai R-Square berkisar antara 0 sampai 1 dengan 
nilai yang mendekati 1 menunjukkan akurasi prediksi semakin besar [9].

\begin{tabular}{|l|r|r|}
\hline & \multicolumn{1}{|l|}{$\begin{array}{l}\text { R } \\
\text { Square }\end{array}$} & $\begin{array}{l}\text { Adjusted R } \\
\text { Square }\end{array}$ \\
\hline $\begin{array}{l}\text { Minat } \\
\text { Pemanfaatan }\end{array}$ & 1.142 & 1.186 \\
\hline $\begin{array}{l}\text { Perilaku } \\
\text { Pengguna }\end{array}$ & 0.802 & 0.779 \\
\hline
\end{tabular}

Gambar 6.R square dan adjusted r square

Berdasarkan nilai R-square yang diperoleh hasil analisis variable minat pemanfaatan adalah 1.142. Nilai R-Square pada variabel perilaku pengguna adalah sebesar 0,802 .

\section{G. PEMBAHASAN}

Signifikansi parameter outer model dapat dievaluasi melalui prosedur resampling bootstrapping dengan tingkat signifikansi $\alpha$ yang digunakan adalah $5 \%$, sehingga nilai ttabel adalah sebesar 1,96 [11]. Berikut ini merupakan hasil pengujian hipotesis:

1. Pengaruh Ekspektasi Kinerja terhadap Minat

Penggunaan Sistem Informasi Perpustakaan.

Ekspektasi kinerja mempunyai nilai t-stastistics sebesar 0.965 yang berarti nilai tersebut dibawah nilai t-tabel 1,96 . Nilai p-values variabel ekspektasi kinerja $(0.335>0,05)$ berarti ekspektasi kinerja tidak berpengaruh terhadap Minat Penggunaan. Besar pengaruh variabel ekspektasi kinerja terhadap minat pemanfaatan sesuai nilai original sample yaitu 0.101 sehingga variabel minat penggunaan mempengaruhi variabel minat pemanfaatan sebesar 10,1\%.Hasil penelitian ini sejalan dengan "Pengaruh Pemanfaatan Dan Penggunaan Sistem Informasi Terhadap Kinerja Individu (Studi Kasus pada Perum BULOG Divisi Regional Jawa Tengah)" diketahui bahwa hipotesis ditolak jika nilai sig. > 0.05 dan nilai thitung < ttabel. Sebaliknya hipotesis diterima jika nilai sig. $<0.05$ dan nilai thitung < ttabel. Hubungan yang menghasilkan nilai berlawanan dengan hipotesis juga akan akan ditolak.

2. Pengaruh Ekspektasi Usaha terhadap Minat Penggunaan Sistem Informasi Perpustakaan.

Ekspektasi Usaha mempunyai nilai t-stastistics sebesar 0.055 yang berarti nilai tersebut dibawah nilai t-tabel 1,96 . Nilai p-values variabel ekspektasi usaha $(0.956>0,05)$ sesuai hasil tersebut menunjukkan bahwa pengaruh sosial tidak berpengaruh positif terhadap minat pemanfaatan. Besar pengaruh variabel ekspektasi usaha terhadap minat pemanfaatan sesuai nilai original sample yaitu -0.006 sehingga variabel minat penggunaan mempengaruhi variabel minat pemanfaatan sebesar - $06 \%$.

Berdasarkan hasil penelitian yang dilakukan oleh () Penerapan Metode Utaut Untuk Memprediksi Behavioral Intentions User Dalam Menggunakan Aplikasi ZABBIX menyatakan bahwa ekspektasi Kinerja (Performance Expectancy) tidak berpengaruh positif terhadap Niat Perilaku Pengguna (Behavioral Intentions User). Hasil penelitian ini menunjukkan bahwa tingkat ukuran dimana pengguna belum percaya pada saat menggunakan teknologi akan membantunya dalam menyelesaikan berbagai permasalahan dalam pekerjaannya.

3. Pengaruh Sosial terhadap Minat Penggunaan Sistem Informasi Perpustakaan.

Pengaruh Sosial mempunyai nilai t-stastistics sebesar 12.874 yang berarti nilai tersebut lebih dari nilai t-tabel 1,96 . Nilai p-values variabel pengaruh sosial $(0,000<0,05)$ sesuai hasil tersebut berarti pengaruh sosial berpengaruh positif terhadap Minat Penggunaan. Besar pengaruh variabel pengaruh social terhadap minat pemanfaatan sesuai nilai original sample yaitu 0.793 sehingga variabel pengaruh social mempengaruhi variabel minat pemanfaatan sebesar $79,3 \%$.

Analisis Faktor-Faktor yang Memengaruhi Niat Penggunaan E-Commerce XYZ Menggunakan Model UTAUT(Mustaqim, Kusyanti, \& Aryadita, 2018)[12]. Dari hasil uji hipotesis dapat disimpulkan bahwa faktor yang berpengaruh terhadap niat untuk bertransaksi di e-commerce XYZ adalah sosial influenceatau pengaruh sosial. Semakin potisif pengaruh sosial seseorang dalam menggunakan Ecommerce XYZ, maka akan semakin besar niat atau keinginan seseorang untuk bertransaksi di e-commerce XYZ 4. Pengaruh Kondisi yang Memfasilitasi terhadap Perilaku Pengguna Sistem Informasi Perpustakaan.

Kondisi yang Memfasilitasi mempunyai nilai t-stastistics sebesar 4.076 yang berarti nilai tersebut diatas nilai t-tabel 1,96. Nilai p-values variabel kondisi yang memfasilitasi $(0,000<0,05)$ sesuai hasil tersebut berarti kondisi yang memfasilitasi berpengaruh positif terhadap perilaku pengguna. Besar pengaruh variabel kondisi memfasilitasi terhadap perilaku pegguna sesuai nilai original sample yaitu 0.460 sehingga variabel kondisi memfasilitasi mempengaruhi variabel minat pemanfaatan sebesar $46 \%$. 
Berdasarkan hasil penelitian yang dilakukan oleh [13], dengan judul "Faktor-faktor yang mempengaruhi penerimaan dan penggunaan sistem informasi pengelolaan keungan daerah (SIPKD) dalam perspektif the unified theory of acceptance and use of technology 2(UTAUT 2) di Kabupaten Semarang" yang menyatakan hasil pengujian hipotesis menunjukkan nilai koefisien jalur sebesar 0,173 , nilai $\mathrm{t}$ statistik 2,779 , dan $\mathrm{p}$ value 0,005 yang berarti facilitating conditions berpengaruh positif dan signifikan terhadap perilaku menggunakan SIPKD, hasil ini dapat diartikan bahwa semakin baik kondisi-kondisi yang memfasilitasi yang disediakan organisasi maka semakin berpengaruh terhadapperilaku menggunakan sistem teknologi informasi[13].

5. Pengaruh Minat Penggunaan terhadap Perilaku Pengguna Sistem Informasi Perpustakaan

Minat Penggunaan mempunyai nilai t-stastistics sebesar 2.569 yang berarti nilai tersebut diatas nilai t-tabel 1,96 . Nilai p-values variabel Minat Penggunaan $(0.010<0,05)$ sesuai hasil tersebut berarti Minat Penggunaan berpengaruh positif terhadap perilaku pengguna. Besar pengaruh variabel minat penggunaan terhadap perilaku pengguna sesuai nilai original sample yaitu 0.299 sehingga variable minat pemanfaatan mempengaruhi variabel perilaku pengguna sebesar $29,9 \%$.

Temuan ini sesuai dengan konsep dasar dari modelmodel penerimaan pengguna yaitu, niat untuk menggunakan teknologi informasi akan mempengaruhi penggunaan sebenarnya teknologi informasi tersebut. Pada penelitianyang berjudul "Pengaruh Behavioral Intention Terhadap Use Behavior Pada Penggunaan Aplikasi Transportasi Online (Studi Kasus Pada Pengguna Go-Jek Dan Grab Di Kalangan Mahasiswa Telkom University)" (Achmad Fauzi1, Teguh Widodo, 2018) Dalam penelitian ini, Behavioral Intention memiliki pengaruh positif dan signifikan terhadap Use Behavior, dengan T-value sebesar 12.70. Ini berarti bahwa semakin banyak pengguna yang bersedia menggunakan layanan transportasi online, itu akan berdampak pada penggunaan layanan di masa mendatang[14].

6. Variabel Moderator Jenis Kelamin Mempengaruhi Ekspektasi Kinerja terhadap Minat Penggunaan Sistem Informasi Perpustakaan.

Variabel moderator jenis kelamin yang mempengaruhi variabel ekspektasi kinerja terhadap Minat Penggunaan mempunyai nilai t-stastistics sebesar 0.497 yang berarti nilai tersebut kurang dari nilai t-tabel 1,96. Nilai p-values variabel moderator jenis kelamin yang mempengaruhi variabel ekspektasi kinerja terhadap Minat Penggunaan $(0.619>0,05)$ sesuai hasil tersebut berarti tidak terdapat efek moderasi jenis kelamin yang memperkuat hubungan antara ekspektasi kinerja terhadap Minat Penggunaan Sistem Informasi Perpustakaan.

Pada penelitian yang berjudul "Faktor-Faktor Yang Berpengaruh Terhadap Penerimaan Aplikasi Brilian Dengan Model UTAUT" (Ntaya, Sunarto, \& Andari, 2018) bahwa jenis kelamin tidak memoderasi hubungan ekspektansi kinerja terhadap minat penggunaan karena nilai t-statistik secara lebih kecil dari 1.96 yaitu 0,07. Pada penelitian Efek Moderasi Dari Usia Dan Jenis Kelamin Dalam Penerimaan E-Ktp Di Kecamatan Gondokusuman Yogyakarta" yang menjelaskan bahwa jenis kelamin tidak mempunyai efek moderasi yang signifikan terhadap hubungan ekspektansi kinerja dengan minat penggunaan dalam penerimaan E-Ktp di Kecamatan Gondokusuman Yogyakarta.

7. Variabel Moderator Umur Mempengaruhi Ekspektasi Kinerja terhadap Minat Penggunaan Sistem Informasi Perpustakaan.

Variabel moderator umur yang mempengaruhi variabel ekspektasi kinerja terhadap minat pemanfaatan mempunyai nilai t-stastistics sebesar 0,773 yang berarti nilai tersebut kurang dari nilai t-tabel 1,96. Nilai p-values variabel moderator umur yang mempengaruhi variabel ekspektasi kinerja terhadap Minat Penggunaan $(0.440>0,05)$ sesuai hasil tersebut berarti tidak terdapat efek moderasi umur yang memperkuat hubungan antara ekspektasi kinerja terhadap Minat Penggunaan.

8. Variabel Moderator Jenis Kelamin Mempengaruhi Ekspektasi Usaha terhadap Minat Penggunaan Sistem Informasi Perpustakaan.

Variabel moderator jenis kelamin yang mempengaruhi variabel ekspektasi usaha terhadap Minat Penggunaan mempunyai nilai t-stastistics sebesar 0.879 yang berarti nilai tersebut kurang dari nilai t-tabel 1,96. Nilai p-values variabel moderator jenis kelamin yang mempengaruhi variabel ekspektasi usaha terhadap Minat Penggunaan (0.380>0,05) sesuai hasil tersebut berarti tidak terdapat efek moderasi jenis kelamin yang memperkuat hubungan antara ekspektasi usaha terhadap Minat Penggunaan.

Hal ini sejalan dengan penelitian yang berjudul "Efek Moderasi Dari Usia Dan Jenis Kelamin Dalam Penerimaan E-Ktp Di Kecamatan Gondokusuman Yogyakarta" yang 
ISSN 2252 - 9063

Kumpulan Artikel Mahasiswa Pendidikan Teknik Informatika

(KARMAPATI)

menunjukkan hasil penelitian bahwa tidak ada pengaruh efek moderasi umur yang memperkuat hubungan ekspektasi kinerja dengan penerimaan E-Ktp di Kecamatan Gondokusuman Yogyakarta.

9. Variabel Moderator Umur Mempengaruhi Ekspektasi Usaha terhadap Minat Penggunaan Sistem Informasi Perpustakaan.

Variabel moderator umur yang mempengaruhi variabel ekspektasi usaha terhadap Minat Penggunaan mempunyai nilai t-stastistics sebesar 0,879 yang berarti nilai tersebut kurang dari nilai t-tabel 1,96. Nilai p-values variabel moderator umur yang mempengaruhi variabel ekspektasi usaha terhadap Minat Penggunaan $(0.603>0,05)$ sesuai hasil tersebut berarti tidak terdapat efek moderasi umur yang memperkuat hubungan antara ekspektasi usaha terhadap Minat Penggunaan Sistem Informasi Perpustakaan.

Hal ini sejalan dengan penelitian yang berjudul "Pengujian Model Unified Theory Of Acceptance And Use Of Technology dalam Pemanfaatan Sistem Informasi Keuangan Daerah". Hasil pengujian mendapatkan bukti empiris bahwa umur memoderasi pengaruh ekspektansi usaha terhadap minat penggunaan SIKD adalah tidak signifikan[14]. Sehingga dapat diartikan bahwa umur tidak memperkuat hubungan ekspektansi usaha dengan minat pemanfaatan SKID.

10. Variabel Moderator Pengalaman Mempengaruhi

Ekspektasi Usaha terhadap Minat Penggunaan Sistem Informasi Perpustakaan.

Variabel moderator pengalaman yang mempengaruhi variabel ekspektasi usaha terhadap Minat Penggunaan mempunyai nilai t-stastistics sebesar 0,521 yang berarti nilai tersebut kurang dari nilai t-tabel 1,96. Nilai p-values variabel moderator pengalaman yang mempengaruhi variabel ekspektasi usaha terhadap Minat Penggunaan (0.937>0,05) sesuai hasil tersebut berarti tidak terdapat efek moderasi pengalaman yang memperkuat hubungan antara ekspektasi usaha terhadap Minat Penggunaan.

Hal ini sejalan dengan penelitian yang berjudul"Pengujian Model Unified Theory Of Acceptance And Use Of Technology dalam Pemanfaatan Sistem Informasi Keuangan Daerah Hasil" dari hasil pengujian menyatakan bahwa pengalaman tidak mempunyai efek memoderasi yang mempengaruhi ekspektansi usaha terhadap minat penggunaan SIKD [14].
11. Variabel moderator Jenis Kelamin Mempengaruhi Pengaruh Sosial terhadap Minat Penggunaan Sistem Informasi Perpustakaan.

Variabel moderator jenis kelamin yang mempengaruhi variabel pengaruh sosial terhadap Minat Penggunaan mempunyai nilai t-stastistics sebesar 0.791 yang berarti nilai tersebut kurang dari nilai t-tabel 1,96. Nilai p-values variabel moderator jenis kelamin yang mempengaruhi variabel pengaruh sosial terhadap Minat Penggunaan (0.429>0,05) sesuai hasil tersebut berarti tidak terdapat efek moderasi jenis kelamin yang memperkuat hubungan antara pengaruh sosial terhadap Minat Penggunaan.

Hasil dari penelitian ini sejalan dengan penelitian yang berjudul "Analisis Sistem Informasi Perpustakaan (SIPUS) Menggunakan Model UTAUT di Perpustakaan Umum Kota Surabaya" yang menyatakan bahwa Jenis kelamin tidak memoderasi hubungan antara pengaruh social terhadap minat penggunaan SIPUS [15].

12. Variabel moderator Umur Mempengaruhi Pengaruh Sosial terhadap Minat Penggunaan Sistem Informasi Perpustakaan.

Variabel moderator umur yang mempengaruhi variabel pengaruh sosial terhadap Minat Penggunaan mempunyai nilai t-stastistics sebesar 1.726 yang berarti nilai tersebut kurang dari nilai t-tabel 1,96. Nilai p-values variabel moderator umur yang mempengaruhi variabel pengaruh sosial terhadap Minat Penggunaan $(0.085>0,05)$ sesuai hasil tersebut berarti tidak terdapat efek moderasi umur yang memperkuat hubungan antara pengaruh sosial terhadap Minat Penggunaan.

Hasil penelitian ini sejalan dengan penelitian yang berjudul Pada penelitian yang berjudul "Faktor-Faktor Yang Berpengaruh Terhadap Penerimaan Aplikasi Brilian Dengan Model UTAUT" hasil dari penelitian ini menunjukkan tidak dimodaerasi oleh umur dibuktikan dengan nilai statistic 0.07 yang lebih kecil dari nilai t-tabel $(1,96)$. Sehingga dapat disimpulkan bahwa umur tidak memperkuat hubungan antara pengaruh social dengan minat pemanfaatan aplikasi Brilian.

13. Variabel Moderator Pengalaman Mempengaruhi Pengaruh Sosial terhadap Minat Penggunaan Sistem Informasi Perpustakaan.

Variabel moderator pengalaman yang mempengaruhi variabel pengaruh sosial terhadap Minat Penggunaan mempunyai nilai t-stastistics sebesar 2.814 yang berarti nilai tersebut kurang dari nilai t-tabel 1,96. Nilai p-values variabel 
moderator pengalaman yang mempengaruhi variabel pengaruh sosial terhadap Minat Penggunaan $(0.005>0,05)$ sesuai hasil tersebut berarti terdapat efek moderasi pengalaman yang memperkuat hubungan antara pengaruh sosial terhadap Minat Penggunaan.

Hasil dari penelitian ini tidak sejalan dengan Pengujian Model Unified Theory Of Acceptance And Use Of Technology dalam Pemanfaatan Sistem Informasi Keuangan Daerah Hasil dari hasil pengujian menyatakan bahwa pengalaman tidak mempunyai efekmemoderasi yang mempengaruhi pengaruh sosial terhadap minat penggunaan SIKD [14].

14. Variabel Moderator Umur Mempengaruhi Kondisi yang Memfasilitasi terhadap Perilaku Pengguna Sistem Informasi Perpustakaan.

Variabel moderator umur yang mempengaruhi variabel kondisi yang memfasilitasi terhadap perilaku pengguna mempunyai nilai t-stastistics sebesar 2.307 yang berarti nilai tersebut lebih dari nilai t-tabel 1,96. Nilai p-values variabel moderator umur yang mempengaruhi variabel kondisi yang memfasilitasi terhadap perilaku pengguna $(0.021<0,05)$ sesuai hasil tersebut berarti terdapat efek moderasi variabel moderator umur yang memperkuat hubungan antara kondisi yang memfasilitasi terhadap perilaku pengguna.

Hasil dari penelitian ini tidak sejalan dengan penelitian yang berjudul "Analisis Sistem Informasi Perpustakaan (SIPUS) Menggunakan Model UTAUT di Perpustakaan Umum Kota Surabaya" yang menyatakan bahwa umur tidak memperkuat hubungan antara kondisi yang menfasilitasi terhadap minat penggunaan SIPUS[15].

15. Variabel Moderator Pengalaman Mempengaruhi Kondisi yang Memfasilitasi terhadap Perilaku Pengguna Sistem Informasi Perpustakaan.

Variabel moderator pengalaman yang mempengaruhi variabel kondisi yang memfasilitasi terhadap perilaku pengguna mempunyai nilai t-stastistics sebesar 3.197 yang berarti nilai tersebut kurang dari nilai t-tabel 1,96. Nilai pvalues variabel moderator pengalaman yang mempengaruhi variabel kondisi yang memfasilitasi terhadap perilaku pengguna $(0.001<0,05)$ sesuai hasil tersebut berarti terdapat efek moderasi pengalaman yang memperkuat hubungan antara kondisi yang memfasilitasi terhadap perilaku pengguna.

Hal ini tidak sejalan dengan penelitian yang berjudul"Pengujian Model Unified Theory Of Acceptance And Use Of Technology dalam Pemanfaatan Sistem
Informasi Keuangan Daerah" Hasil pengujian mendapatkan bukti empiris bahwa pengalaman tidak memoderasi pengaruh kondisi pemfasilitasi terhadap minat penggunaan SIKD [14].

\section{KESIMPULAN DAN SARAN}

\section{A. KESIMPULAN}

Pengaruh Sosial berpengaruh positif terhadap Minat Penggunaan Sistem Informasi Perpustakaan. Pengguna percaya bahwa image seseorang dapat mempengaruhi minat dari penggunaan sistem informasi perpustakaan. Kondisi yang memfasilitasi berpengaruh positif terhadap perilaku penggunaan Sistem Informasi Perpustakaan pengguna merasa bahwa fasilitas yang ada sangat mendukung penggunaan Sistem Informasi Perpustakaan serta, komputer, $\mathrm{hp}$, jaringan internet juga sangat membantu pengguna dalam mengoperasikan Sistem Informasi Perpustakaan sehingga fasilitas ini sangat dibutuhkan untuk melakukan proses peminjaman buku. Sedangkan pada Minat penggunaan juga berpengaruh positif terhadap perilaku pengguna Sistem Informasi Perpustakaan pengguna pengguna berniat untuk terus menggunakan Sistem Informasi Perpustakaan dalam melakukan proses peminjaman buku, sehingga dari niat tersebut mencerminkan pengguna akan terus menggunakan Sistem Informasi Perpustakaan.

Variabel moderator Pengalaman yang memperkuat hubungan antara Kondisi yang Memfasilitasi terhadap Perilaku Pengguna Sistem Informasi Perpustakaan memiliki nilai t-statistics dari variabel moderator Pengalaman pada faktor Kondisi yang Memfasilitasi terhadap variabel Perilaku Pengguna lebih besar dari nilai t-tabel $(1,96)$ yaitu 3.197. Variabel moderator umur yang memperkuat hubungan antara Kondisi yang Memfasilitasi terhadap Perilaku Pengguna Sistem Informasi Perpustakaan. memiliki nilai t-statistics dari variabel moderator Umur pada faktor Kondisi yang Memfasilitasi terhadap variabel Perilaku Pengguna lebih besar dari nilai t-tabel $(1,96)$ yaitu 2.307 . Variabel moderator jenis kelamin tidak memperkuat hubungan antara ekspektasi kinerja dengan prilaku pengguna layanan Sistem Informasi Perpustakaan, ekspektasi usaha dengan prilaku pengguna Sistem Informasi Perpustakaan, faktor sosial dengan prilaku pengguna Sistem Informasi Perpustakaan, dan kondisi yang memfasilitasi dengan prilaku pengguna Sistem Informasi Perpustakaan.

\section{B. SARAN}

Berdasarkan hasil penelitian yang telah dilakukan, analisa penerimaan dan penggunaan Sistem Informasi Pengadilan dengan Model Unified Theory of Acceptance and Use of Technology memiliki potensi untuk 
dikembangkan menjadi lebih baik lagi. Oleh karena itu, peneliti mencoba memberikan saran yang sekiranya dapat berguna untuk peneltian selanjutnya, antara lain:

1. Untuk pengelola Sistem Informasi Perpustakaan peneliti berharap pengelola mampu mengadakan kegiatan yang dapat mensosialisasikan kepada masyarakat,menggunakan sistem informasi perpustakaan dapat meningkatkan kinerja dalam melakukan proses peminjaman buku. Sistem Informasi Perpustakaan merupakan sistem yang mudah diakses dengan cepat dalam melakukan pekerjaan dan pengguna tidak membutuhkan watktu yang lama untuk menggunakan sistem informasi perpustakaan.

2. Untuk penelitian selanjutnya berdasarkan rekomendasi yang peneliti berikan, peneliti berharap mampu melanjutkan rekomendasi tersebut agar sistem informasi pengadilan semakin optimal dalam penggunaanya

\section{RFERENSI}

[1] Handayani, T., \& Sudiana, S. (2015). Analisis Penerapan Model Utaut (Unified Theory of Acceptance and Use of Technology) Terhadap Perilaku Pengguna Sistem Informasi (Studi Kasus: Sistem Informasi Akademik Pada Sttnas Yogyakarta). Angkasa: Jurnal Ilmiah Bidang Teknologi, 7(2), 165-180.

[2] Muttaqien, M. Z., \& Kusumayadi, E. (2012). DasarDasar Teknologi Informasi. Tanggerang Selatan: Universitas Terbuka.

[3] Setiawan, A. (2018). Pengaruh Penerapan Remote Electronic Voting System (REVS) Terhadap Tingkat Partisipasi Pemilih Menggunakan Model UTAUT. JTT (Jurnal Teknologi Terapan), 3(1), 1-6. https://doi.org/10.31884/jtt.v3i1.1

[4] Viswanath Venkatesh, Michael G . Morris , Gordon B . Davis, F. D. . D. (2003). User Acceptance of Information Technology: Toward a Unified View Published by: Management Information Systems Research Center , University of Minnesota, 27(3), 425-478.

[5] Sumertajaya, I. G. N. M. J. I. M. (2008). Pemodelan persamaan structural yang sering disebut dengan. Semnas Matematika Dan Pendidikan Matematika UNPAD, 118132.

[6] Sugiyono. (2010). Metode Penelitian Pendidikan Pendekatan Kuantitatif, Kualitatif, dan R\&D. Bandung: Alfabeta.
[7] Bungin, B. (2008). Metodologi Penelitian Kuantitatif: Komunikasi, Ekonomi, dan Kebijakan Publik Serta IlmuIlmu Sosial Lainnya. jakarta: prenada media group.

[8] Arikunto, S. (2014). Prosedur Penelitian. jakarta: Rineka Cipta.

[9] Santoso, P. I. (2018). Metode Penelitian Kuantitatif Pengembangan Hipotesis dan Pengujiaannya Menggunakan SmartPLS. Yogyakarta: Penerbit ANDI.

[10] Sugihartini, N., \& Agustini, K. (2018). Cara Cepat Mengembangkan Instrumen dan Teknik Analisisnya. Raja Grafindo Persada, 4(2), 1-10.

[11] Wulandari, N. P. A., \& Yadnyana, I. K. (2016). PENERAPAN MODEL UNIFIED THEORY OF ACCEPTANCE AND USE OF TECHNOLOGY DI KOTA DENPASAR, 1270-1297.

[12]Mustaqim, R. N., Kusyanti, A., \& Aryadita, H. (2018). Analisis Faktor-Faktor yang Memengaruhi Niat Penggunaan E-Commerce XYZ Menggunakan Model UTAUT ( Unified Theory Acceptance and Use Of Technology ), 2(7), 2584-2593.

[13] Sutanto, Ghozali, I., \& Handayani, R. S. (n.d.). Faktorfaktor yang Mempengaruhi Penerimaan dan Penggunaan Sistem Informasi Pengelolaan Keuangan Daerah (SIPKD) Dalam Persektif The Unified Theory Of Acceptance And Use Of Technology 2 (UTAUT 2) DiKabupaten Semarang, 15(1), 37-68.

[14] Achmad Fauzi1, Teguh Widodo, T. D. (2018). Pengaruh Behavioral Intention terhadap Use Behavior pada Penggunaan Aplikasi Transportasi Online ( Studi kasus pada pengguna Go-jek dan Grab di Kalangan Mahasiswa Telkom University ), (October).

[15]Dini Berliana. (2012). Analisis Sistem Informasi Perpustakaan (Sipus) Menggunakan Model Unified Theory Of Acceptance And Use Of Technology (Utaut) Di Perpustakaan Umum Kota Surabaya1 Dini. Issn. 